\title{
The Analysis of Household Owning/Renting House during and before the Financial Crisis
}

\author{
Bing Chen
}

\begin{abstract}
This paper analyzes the household owning/renting house behavior and transitions between home owners and renters during and before the financial crisis, including an extension analysis for the time period of 2009-2011. I found some different household behaviors between before the financial crisis and during the financial crisis. Education level, age, employment status, household income, and household wealth level have significant effects on the household owning/renting house and/or transitions between home owners and renters. Two mortgage distress indexes are built in this paper, and the empirical results indicate a significant effect of mortgage distress on the transition from home owner to renter in the period of 2009-2011.
\end{abstract}

Index Terms-Household, owning/renting house, financial crisis.

\section{INTRODUCTION}

Housing is one of the biggest assets for each household [1], [2], and the household decision about owning/renting a house, mortgage payment, etc. and the change in home equity after the financial crisis can have big effects on household consumption and other expenditures [3]-[5], and then have significant effects on the financial market because of the integration between the real estate market and the stock market [6], [7]. For example, the 2008 financial crisis is triggered by the collapse of the real estate market.

During the financial crisis, lots of household closed their mortgages because of payment problems and lost their houses, while, some other households bought their houses during the financial crisis, maybe, because they thought the housing price is relatively low at that time. The switch between home owner and renter can greatly change the real estate market because of the change of house demand and supply.

This paper focuses on the analysis of household owning/renting behavior and the possible important factors which can significantly affect household owning/renting decision. The rest of the paper is organized as following: Section II outlines the data and model; Section III shows the empirical analysis; Section IV presents the conclusion.

\section{DATA AND MODEL}

The main family data from Panel Study of Income Dynamics (PSID) is used for the analysis in this paper. PSID is a database funded by the National Science Foundation

Manuscript received November 25, 2013; revised January 6, 2014. The author appreciates the comments from Dr. Peter Lenk.

Bing Chen is with the Economics Department, Bowdoin College, Brunswick, ME 04011 USA (e-mail: bchen@bowdoin.edu). since 1968. There are more than 5000 US households that are surveyed in the PSID data, and the survey questions cover many aspects of household, such as housing, consumption, pension, wealth, education, etc. For each survey, some new households may just join the survey pool, and some previous surveyed households may just leave the survey pool. PSID do the survey every other year. This paper uses the PSID survey data in 2005, 2007, 2009, and 2011.

There is a core/immigrant family weight number for each observation in the PSID data. The 2007, 2009, and 2011 weights are used for the logit regression analysis in the period of 2005-2007, 2007-2009, and 2009-2011. Using those weight numbers can expand the sample size in some sense and make the results more persuasive. To focus the analysis on the home owners and renters, I exclude the households who reported neither home owners nor renters. Some observations with invalid or extreme values are also excluded.

\section{EMPIRICAL ANALYSIS}

\section{A. Transition Statistics between Home Owner and Renter}
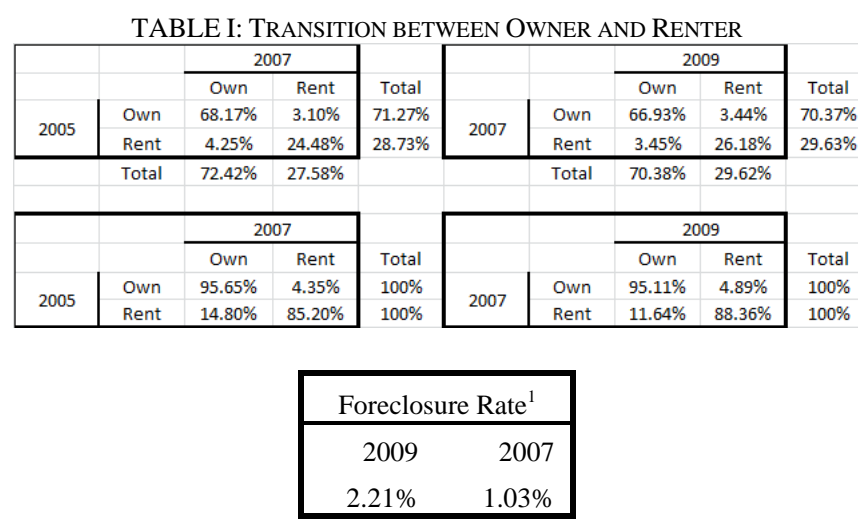

Table I shows the transition between home owner and renter in the time period of 2005-2007 and 2007-2009. Compared with the household actions before the financial crisis, there are significantly fewer transitions from renter to home owner and slightly more transitions from home owner to renter during the financial crisis. There are three main reasons for the fewer transitions from renter to home owner in the period of 2007-2009. First, most households suffered financial losses during the financial crisis, which decreased the overall household wealth; second, it was hard to get a mortgage during the financial crisis because the banks greatly increased the criteria of taking a mortgage; third, many

\footnotetext{
${ }^{1}$ Data Source: http://www.wsws.org/en/articles/2010/01/home-j16.html Those foreclosure rates are ratios with respect to all households.
} 
people worried about the stability of their jobs and their future financial situation during the financial crisis, and then they were more likely to keep cash and reluctant to buy houses during the financial crisis.

TABLE II: LOGIT REGRESSION RESULTS FOR THE PERIOD OF 2005-2007 AND 2007-2009

\begin{tabular}{|c|c|c|c|c|c|c|}
\hline & \multicolumn{2}{|c|}{ Own/Rent $(O w n=1)$} & \multicolumn{2}{|c|}{ Switch to Home Owner } & \multicolumn{2}{|c|}{ Switch to Renter } \\
\hline & 2007-2009 & $2005-2007$ & 2007-2009 & $2005-2007$ & 2007-2009 & $2005-2007$ \\
\hline \multirow[t]{2}{*}{ Intercept } & 0.1733 & $0.3513^{* *}$ & $-3.5742^{* * *}$ & $-4.0912^{* * *}$ & $-2.3663^{* * *}$ & $-2.744 * * *$ \\
\hline & $(0.1768)$ & $(0.1768)$ & $(0.4896)$ & $(0.532)$ & $(0.339)$ & $(0.4703)$ \\
\hline \multirow[t]{2}{*}{$2<\#$ of person in the household $<=5$ in $09(07)$} & $0.2573^{* *}$ & 0.176 & 0.3161 & 0.0557 & $-0.5799 * * *$ & -0.1171 \\
\hline & $(0.1069)$ & $(0.1073)$ & (0.1984) & $(0.1961)$ & $(0.2241)$ & (0.2239) \\
\hline \multirow[t]{2}{*}{ \# of person in the household $>5$ in $09(07)$} & 0.3022 & 0.2477 & 0.0818 & $0.6451^{*}$ & 0.0287 & 0.6464 \\
\hline & $(0.2072)$ & $(0.22)$ & $(0.4822)$ & $(0.3702)$ & $(0.3977)$ & $(0.4452)$ \\
\hline \multirow[t]{2}{*}{ age_head_09 $(07)<=34$} & $-1.6738^{* * *}$ & $-1.4427^{* * *}$ & 0.0862 & $1.8268^{* * *}$ & $0.802^{* *}$ & $0.9245^{* *}$ \\
\hline & $(0.1736)$ & $(0.179)$ & $(0.5309)$ & $(0.5247)$ & $(0.3519)$ & $(0.3724)$ \\
\hline \multirow[t]{2}{*}{ 34<age_head_09 $(07)<=49$} & $-0.9457^{* * *}$ & $-0.9139 * * *$ & -0.0915 & $1.6399 * * *$ & 0.3024 & $0.6524^{*}$ \\
\hline & (0.1711) & $(0.1742)$ & $(0.5332)$ & $(0.5192)$ & $(0.3464)$ & $(0.347)$ \\
\hline \multirow[t]{2}{*}{ 49<age_head_09 $(07)<=64$} & $-0.3404^{* *}$ & -0.2026 & -0.0992 & $1.4711^{* * *}$ & -0.3456 & -0.2328 \\
\hline & $(0.1562)$ & $(0.1636)$ & $(0.5455)$ & $(0.527)$ & $(0.2963)$ & $(0.329)$ \\
\hline \multirow[t]{2}{*}{ edu_head_09 (07) $=12$} & $0.2685^{* *}$ & $0.3965^{* * *}$ & 0.29 & 0.2393 & 0.3146 & 0.2413 \\
\hline & $(0.1236)$ & $(0.1214)$ & $(0.3032)$ & $(0.2603)$ & $(0.2939)$ & $(0.3243)$ \\
\hline \multirow[t]{2}{*}{$12<e d u \_h e a d \_09(07)<=16$} & $0.2568^{* *}$ & $0.3484^{* * *}$ & $0.6161^{* *}$ & $0.689 * * *$ & 0.1979 & 0.1911 \\
\hline & $(0.1293)$ & $(0.129)$ & $(0.2863)$ & $(0.2625)$ & (0.3099) & $(0.3433)$ \\
\hline \multirow[t]{2}{*}{ edu_head_09 (07)=17 } & $0.3618^{*}$ & $0.3396^{*}$ & $0.8355^{* *}$ & -0.0176 & -0.358 & -0.4429 \\
\hline & $(0.1984)$ & $(0.2029)$ & $(0.3826)$ & $(0.4186)$ & $(0.435)$ & $(0.4771)$ \\
\hline \multirow[t]{2}{*}{ Employed_head_07 (05) } & -0.0172 & -0.2507 & 0.0986 & -0.1987 & -0.2277 & 0.0757 \\
\hline & $(0.1336)$ & $(0.1538)$ & $(0.2945)$ & $(0.2799)$ & $(0.2817)$ & $(0.3254)$ \\
\hline \multirow[t]{2}{*}{ Employed_wife_07 (05) } & 0.1736 & -0.1073 & 0.3794 & -0.4969 & -0.289 & $1.121^{* * *}$ \\
\hline & $(0.1594)$ & $(0.162)$ & $(0.2771)$ & (0.3089) & $(0.3475)$ & $(0.3496)$ \\
\hline \multirow[t]{2}{*}{ No_wife_07 (05) } & 0.0369 & $-0.5094^{* *}$ & -0.0174 & -0.0433 & $-1.9673^{* * *}$ & $-0.9834^{*}$ \\
\hline & $(0.2631)$ & $(0.2499)$ & $(0.417)$ & $(0.4392)$ & $(0.5324)$ & $(0.5244)$ \\
\hline \multirow[t]{2}{*}{ Employed_head_09(07) } & 0.0756 & 0.1423 & $0.7105^{* * *}$ & 0.1358 & -0.1057 & -0.2548 \\
\hline & $(0.1305)$ & $(0.152)$ & $(0.2649)$ & $(0.2985)$ & $(0.2906)$ & $(0.3223)$ \\
\hline \multirow[t]{2}{*}{ Employed_wife_09 (07) } & -0.0057 & 0.0877 & 0.033 & 0.4016 & 0.2112 & $-0.9659^{* * *}$ \\
\hline & (0.1519) & $(0.1566)$ & $(0.2663)$ & $(0.2885)$ & $(0.3679)$ & $(0.3101)$ \\
\hline \multirow[t]{2}{*}{ No_wife_09 (07) } & $-0.9929 * * *$ & $-0.5134^{* *}$ & -0.5957 & -0.5075 & $2.6449^{* * *}$ & $1.6571^{* * *}$ \\
\hline & $(0.2591)$ & $(0.254)$ & $(0.4136)$ & $(0.4551)$ & $(0.5341)$ & $(0.5129)$ \\
\hline \multirow[t]{2}{*}{$10<$ wealth excluding home equity_07 $(05)(K)<=65$} & $0.9641^{* * *}$ & $0.7274^{* * *}$ & 0.3214 & 0.1707 & $-0.5532 * *$ & -0.3324 \\
\hline & $(0.1054)$ & $(0.1064)$ & $(0.2265)$ & $(0.2083)$ & $(0.2324)$ & $(0.241)$ \\
\hline \multirow[t]{2}{*}{ wealth excluding home equity_07 (05) $(\mathrm{K})>65$} & $1.4005^{* * *}$ & $1.4002^{* * *}$ & 0.2137 & $0.6466^{* *}$ & $-1.1459 * * *$ & $-0.7922^{* * *}$ \\
\hline & $(0.1321)$ & $(0.1339)$ & $(0.3163)$ & $(0.3155)$ & $(0.2748)$ & $(0.2859)$ \\
\hline \multirow[t]{2}{*}{ Increase of family income $06-08(04-06)(\mathrm{K})$} & $-0.0072^{* * *}$ & $-0.0054^{* *}$ & 0.0004 & -0.0022 & 0.0025 & -0.0029 \\
\hline & $(0.0024)$ & $(0.00263)$ & $(0.0038)$ & $(0.0035)$ & $(0.0042)$ & $(0.0031)$ \\
\hline \multirow[t]{2}{*}{ Family income in $08(06)(\mathrm{K})$} & $0.0149^{* * *}$ & $0.0176^{* * *}$ & $0.0104^{* * *}$ & $0.0131^{* * *}$ & -0.0031 & $-0.0114^{* * *}$ \\
\hline & $(0.0021)$ & $(0.00219)$ & $(0.0028)$ & $(0.0033)$ & $(0.0029)$ & (0.0039) \\
\hline
\end{tabular}

*,** and *** mean statistical significance at the $10 \%, 5 \%$, and $1 \%$ levels.

There are two main reasons that households transit from home owners to renters. First, people have mortgage payment troubles and foreclosure their mortgages; second, the retired senior people sell their houses and become renters. Although the percentages of households transited from home owner to renter are similar for the period of 2007-2009 (3.44\%) and the period of 2005-2007 (3.10\%), the mortgage foreclosure rate in $2009(2.21 \%)$ is much higher than the foreclosure rate in $2007(1.03 \%)$. Most of the transitions from home owner to renter are because of mortgage foreclosure in the period of 2007-2009, while less than half of the transitions from home owner to renter are because of mortgage foreclosure in the period of 2005-2007. Additionally, since the financial crisis occurred at the end of 2008 and many households were surveyed in the first half of 2009, many of the coming mortgage foreclosures were not captured by the 2009 PSID survey.

\section{A. Regression Analysis of Owning/Renting}

To analyze what are the main factors that affect household decision of owning/renting house and whether those factors changed during the financial crisis, compared with the period before the financial crisis, I run logit regressions for both the period of 2007-2009 and 2005-2007. For the 2007-2009 regression, the dependent variable is a dummy variable indicating whether the household is a home owner in 2009 (1-home owner; 0-renter). The independent variables include: the number of persons in the household in 2009 , the age group of the household head in 2009, the education level of the household head in 2009, the employment status of head and wife in 2007, whether no wife 2 in the household in 2007, the employment status of head and wife in 2009 , whether no

\footnotetext{
2 "No wife" means the household head is single. The head can be either male or female.
} 
wife in the household in 2009, the household wealth level excluding home equity in 2007, the increase of annual family income from 2006 to 2008, and the family income in 2008. (In the 2009 PSID survey, the annual family income in 2008 was reported; no family income (or expected) in 2009 was reported.) For the 2005-2007 regression, I just move backward two years for each variable and run the similar regression.

TABLE III: LOGIT REGRESSION RESULTS FOR THE PERIOD OF 2009-2011

\begin{tabular}{|c|c|c|c|c|}
\hline & \multirow[t]{2}{*}{ Own/Rent $(O w n=1)$} & \multirow[t]{2}{*}{ Switch to Home Owner } & \multicolumn{2}{|c|}{ Switch to Renter } \\
\hline & & & Index 1 & Index 2 \\
\hline \multirow[t]{2}{*}{ Intercept } & $0.3859 * *$ & $-3.0814^{* * *}$ & $-3.344 * * *$ & $-3.4797^{* * *}$ \\
\hline & $(0.1736)$ & $(0.4423)$ & $(0.3585)$ & $(0.3617)$ \\
\hline \multirow[t]{2}{*}{$2<\#$ of person in the household $<=5$ in 11} & $0.2172^{* *}$ & 0.105 & 0.078 & 0.065 \\
\hline & $(0.1049)$ & $(0.2146)$ & $(0.2197)$ & $(0.2193)$ \\
\hline \multirow[t]{2}{*}{ \# of person in the household $>5$ in 11} & 0.1872 & -0.4959 & -0.4201 & -0.458 \\
\hline & $(0.2159)$ & $(0.4989)$ & $(0.4924)$ & $(0.4863)$ \\
\hline \multirow[t]{2}{*}{ age_head_11<=34 } & $-2.2085^{* * *}$ & 0.1404 & $2.1615^{* * *}$ & $2.1856^{* * *}$ \\
\hline & $(0.1676)$ & $(0.4008)$ & $(0.3529)$ & $(0.3521)$ \\
\hline \multirow[t]{2}{*}{ 34<age_head_11<=49 } & $-1.2235^{* * *}$ & 0.0737 & $1.3166^{* * *}$ & $1.3459^{* * *}$ \\
\hline & $(0.1673)$ & $(0.4122)$ & $(0.323)$ & (0.3199) \\
\hline \multirow[t]{2}{*}{ 49<age_head_11<=64 } & $-0.4614^{* * *}$ & 0.4395 & 0.0874 & 0.1326 \\
\hline & (0.1489) & $(0.4114)$ & $(0.295)$ & (0.291) \\
\hline \multirow[t]{2}{*}{ edu_head_11=12 } & $0.3483^{* * *}$ & 0.2697 & -0.2993 & -0.3153 \\
\hline & $(0.1274)$ & $(0.2822)$ & $(0.3114)$ & $(0.3092)$ \\
\hline \multirow[t]{2}{*}{$12<e d u$ head_11<=16 } & $0.4253^{* * *}$ & $0.4718^{*}$ & -0.5065 & -0.52 \\
\hline & $(0.1318)$ & $(0.2666)$ & $(0.3228)$ & $(0.3216)$ \\
\hline \multirow[t]{2}{*}{ edu_head_11=17 } & $0.4645^{* *}$ & 0.4153 & -0.1922 & -0.2205 \\
\hline & (0.1978) & $(0.4103)$ & (0.3899) & $(0.3888)$ \\
\hline \multirow[t]{2}{*}{ Employed_head_09 } & $0.2166^{*}$ & 0.1752 & -0.374 & -0.397 \\
\hline & $(0.1238)$ & $(0.2721)$ & $(0.2956)$ & $(0.2948)$ \\
\hline \multirow[t]{2}{*}{ Employed_wife_09 } & -0.0234 & 0.0079 & 0.3844 & 0.3754 \\
\hline & $(0.1472)$ & $(0.2855)$ & $(0.3024)$ & (0.2999) \\
\hline \multirow[t]{2}{*}{ No_wife_09 } & -0.227 & 0.4719 & -0.7251 & -0.7473 \\
\hline & $(0.2148)$ & $(0.3927)$ & $(0.463)$ & $(0.4562)$ \\
\hline \multirow[t]{2}{*}{ Employed_head_11 } & 0.104 & 0.4133 & -0.2399 & -0.2461 \\
\hline & $(0.1256)$ & $(0.2978)$ & $(0.3158)$ & $(0.3147)$ \\
\hline \multirow[t]{2}{*}{ Employed_wife_11 } & $0.3246^{* *}$ & 0.0305 & $-1.2494^{* * *}$ & $-1.2251^{* * *}$ \\
\hline & $(0.1456)$ & $(0.2696)$ & $(0.3097)$ & $(0.3079)$ \\
\hline \multirow[t]{2}{*}{ No_wife_11 } & $-0.7757^{* * *}$ & $-1.1811^{* * *}$ & $1.2628^{* * *}$ & $1.2781^{* * *}$ \\
\hline & $(0.211)$ & $(0.3957)$ & $(0.4606)$ & $(0.4551)$ \\
\hline \multirow[t]{2}{*}{$10<$ wealth excluding home equity_09 $(\mathrm{K})<=65$} & $0.8158^{* * *}$ & 0.0982 & 0.1633 & 0.1533 \\
\hline & $(0.1018)$ & $(0.2239)$ & $(0.2205)$ & $(0.2193)$ \\
\hline \multirow[t]{2}{*}{ wealth excluding home equity_09 $(K)>65$} & $1.3097 * * *$ & 0.1062 & -0.141 & -0.1422 \\
\hline & $(0.1319)$ & $(0.2992)$ & $(0.2733)$ & $(0.2735)$ \\
\hline \multirow[t]{2}{*}{ Increase of family income $08-10(\mathrm{~K})$} & -0.0014 & 0.0008 & $-0.0052^{*}$ & $-0.0053^{*}$ \\
\hline & $(0.002)$ & $(0.0038)$ & $(0.0031)$ & $(0.0031)$ \\
\hline \multirow[t]{2}{*}{ Family income in $10(\mathrm{~K})$} & $0.0093^{* * *}$ & $0.0071^{* *}$ & 0.0023 & 0.0022 \\
\hline & $(0.002)$ & $(0.003)$ & $(0.0025)$ & $(0.0025)$ \\
\hline \multirow[t]{2}{*}{ Mortgage distress Index 1} & & & $2.3751^{* * *}$ & \\
\hline & & & $(0.4189)$ & \\
\hline \multirow[t]{2}{*}{ Mortgage distress Index 2} & & & & $0.731^{* * *}$ \\
\hline & & & & $(0.1307)$ \\
\hline
\end{tabular}

According to the results in Table II, we can see that young people are less likely to own houses than older people in both the period of 2007-2009 and 2005-2007(the excluded age group is "the household head is older than 64"). Typically, people start from renting a house, and then buy a house when he/she get a stable job and get married. The household headed by person with higher education level is more likely to own a house. For the period of 2007-2009, the household headed by person with some post-graduate education (edu_head_09=17) is much more likely to own a house, compared with households headed by people in the other education level groups. A person with higher education level is more likely to get a stable job and better future financial status, and it is easier for him/her to get a mortgage from a bank during the financial crisis, and then more likely to own a house. The employment status of head and wife play no role in this analysis because none of the related coefficient is significantly different from zero. It seems that single people are more likely to rent houses. This result makes sense because, typically, most people would buy houses only after they get married.

The household wealth level significantly affects the owning/renting decision in both the period of 2007-2009 and the period of 2005-2007. There is no surprise that rich people are more likely to be home owners than poor people. Households with more wealth in 2007 (2005) are more likely 
to become home owners in 2009 (2007). For the rich people (wealth excluding home equity $>65 \mathrm{~K}$ ), there is no significant difference between the estimated coefficients in the period of 2007-2009 and in the period of 2005-2007. But, for the households in the middle wealth group $(10 \mathrm{~K}<$ wealth excluding home equity $<=65 \mathrm{~K})$, they were much more likely to become home owners than the poor households (wealth excluding home equity $<=10 \mathrm{~K}$ ) in the period of 2007-2009 with the estimated coefficient of 0.9641 . But, they were not that more likely to become home owners in the period of 2005-2007 with the estimated coefficient of 0.7274. During the financial crisis, banks increased the criteria of taking a mortgage, and then households in the middle wealth group were more likely to get mortgages because of better financial situations than the poor households. But, during the good time (2005-2007), it was easy for every household to get a mortgage from a bank, and thus the households in the middle wealth group were not that more likely to become home owners than the poor households.

For the effect of family income, the households with more annual family income in 2008 (2006) are more likely to be home owners in 2009 (2007). The estimated coefficients of "increase of family income 06-08 (04-06)" are negative. This is an unexpected result. But, its scale is much smaller than the scale of the estimated coefficient of "family income".

\section{A. Regression Analysis of Switching from Renter to Home Owner}

In this section, I analyze the transition from renter to home owner. For the sample in the period of 2007-2009, only the households who were renters in 2007 are included. The dependent variable is a dummy variable (1-renter in 2007 and home owner in 2009; 0-renter in both 2007 and 2009). The same dependent variables included in the logit regression in section 3.2 are used. The similar logit regression is exploited for the period of 2005-2007.

According to the results in Table II, we can see that young people were significantly more likely to switch from renters to home owners than old people during the good period of 2005-2007. But, we do not find the similar significant result for the period of 2007-2009. During the normal or good period, young people need to buy houses after they get stable jobs and get married. But, during the financial crisis, most of their jobs became unstable and there were lots of uncertainties for the future, and thus we do not find the similar result in the period of 2007-2009.

Conditional on the control of family income, the households headed by persons with some college education were significantly more likely to become home owners than the households headed by persons without some college education in both the period of 2007-2009 and the period of 2005-2007. As what we discussed early, people with higher education level are more likely to have stable jobs and get mortgages from banks. For the households headed by persons with post-graduate education, they are significantly more likely to become home owners in 2009 than those households headed by people with lower education level. But, we do not find the similar result in the period of 2005-2007. This indicates that banks became really careful for the job and income stability of the mortgage applicants during the financial crisis, while they were not that sensitive to the job and income stability in the good time period (2005-2007).

Overall, the employment status of head and wife and marriage status do not play significant roles in the switching from renter to home owner. The estimated coefficients for the wealth level excluding home equity and the increase of annual family income are not significant, except for the estimated coefficient of "wealth excluding home equity in $05>65 \mathrm{~K}$ ". But, the signs of all those estimated coefficients are positive. The estimated coefficients of annual family income are significant for both the period of 2007-2009 and the period of 2005-2007. The higher wealth and income level, the more able for a household to transit from renter to home owner.

\section{B. Regression Analysis of Switching from Home Owner to Renter}

The transition from home owner to renter is analyzed in this section. In the sample for the period of 2007-2009, only those households who were home owners in 2007 are included in the sample. The dependent variable is a dummy variable (1-home owner in 2007 and renter in 2009; 0-home owner in both 2007 and 2009). The same dependent variables in the logit regression in section 3.2 are used. The similar logit regression is leveraged for the period of 2005-2007. The regression results are shown in Table II.

In the period of 2007-2009, households with more than 2 and less than 5 persons were significantly less likely to transit from home owners to renters. Young people were more likely to transit from home owners to renters in both the period of 2007-2009 and the period of 2005-2007. There are two main reasons for this result. First, young people are more likely to have unstable jobs and meet negative financial shocks because of layoff or unemployment; Second, young people have less financial assets as buffer assets when they meet unexpected negative financial shocks. Then, young people are more likely to foreclosure their mortgages when they meet unexpected negative financial shocks. The education level does not significantly matter for the transition from home owner to renter.

The employment status of head does not play a significant role. One interesting finding is that, for the logit regression of 2005-2007, a positive employment status of wife in 2005 can increase the probability of switching to renter in 2007, while a positive employment status of wife in 2007 can decrease the probability of switching to renter in 2007. The second result is trivial, but the first one is not. The households with positive wife employment status in 2005 were more likely to take big and risky mortgage positions in 2005 because both those households and banks were more likely to take/issue big mortgages during the real estate bubble, and those households allocated a big proportion of family income to pay mortgage each month. After taking the risky mortgages, those households were more likely to have mortgage payment troubles if they met negative financial shocks, and then they had to foreclosure their mortgages and switched from home homers to renters.

The households with single head in 2007 (2005) were less likely to switch from home owners to renters in 2009 (2007), while the households with single head in 2009 (2007) were 
more likely to switch from home owners to renters in 2009 (2007).

Households with more wealth were significantly less likely to switch from home owners to renters. Additionally, the high annual family income can significantly decrease the probability of switching from home owner to renter in the period of 2005-2007. Although the estimated coefficient of "family income in 08 " is not significant, its sign also is negative. Households with high wealth and family income level have more financial buffer assets when they meet negative financial shocks, and then they are less likely to foreclosure their mortgages and switch from home owners to renters.

\section{Extension to the Period of 2009-2011}

In this section, I will extend the analysis to the period of 2009-2011. PSID just released the 2011 mail family survey data on July 30, 2013. There are two main reasons why the analysis in the period of 2009-2011 is interesting. First, some effects of the 2008 financial crisis may not be captured by the 2009 survey data because the financial crisis just started at the 2009 survey time. Second, we can include one important factor, the mortgage payment distress, in our analysis for the period of 2009-2011. PSID started to measure the mortgage payment distress in the 2009 survey. There are three mortgage distress measures in the 2009 PSID survey:

(m1) Whether Behind on Mortgage (ER42025)

( $m 2$ ) Whether Restructured Mortgage because of the missed payment (ER42057)

(m3) Likely to Fall Behind on Mortgage in the Next 12 Months (ER42058)

I define $m 1=1$ if the answer is "yes", $=0$ if the answer is "no"; $m 2=1$ if the answer is "yes", =0 if the answer is "no"; $m 3=1$ if the answer is "very likely", $=0.5$ if the answer is "somewhat likely", =0 if the answer is "not at all likely".

To capture the effect of mortgage distress, I build two mortgage distress indexes through two different ways. Those two mortgage distress indexes can work together for the robust check. The first index is generated by the Principal Component Analysis. Since we cannot apply Principal Component Analysis directly for the dummy variables, we need to transform the dummy variables before applying for Principal Component analysis. According to the method of Stafford and Chen [8], first, I run the OLS regressions of each measure, using the other two measures as independent variables. I keep the fitted value for each regression. Those fitted values are not dummy variables any more, and they capture the common parts of $m 1, m 2$, and $m 3$. Second, I apply Principal Component analysis for those fitted values, and define the first principal component as mortgage distress index 1 . The second mortgage distress index is generated by the sum of the values of $m 1, m 2$ and $m 3$.

Table III presents the regression results for the period of 2009-2011. Most conclusions we get for the period of 2007-2009 are still true for the period of 2009-2011.But, there are also some different results for the period of 2009-2011. The following are three main differences.

First, the employment status of head in 2009 is significantly matter in owning/renting house. A household with employed head was more likely to own a house, but we do not find the similar result for the period of 2007-2009. In 2007 , it is very easy for a household to get a mortgage, no matter what is the head employment status, but, in 2009 , banks became careful for the mortgage issuing. A household with unemployed head was less likely to get a mortgage, and then less likely to own a house.

Second, the estimated coefficient for the increase of family income from 2008 to 2010 is not negatively significant for owning/renting house in the regression for owning/renting house. But, the corresponding estimated coefficients for the period of 2005-2007 and 2007-2009 are significantly negative. Those negative coefficients do not make sense. The household expectation may explain those negative estimated coefficients. Even though the family incomes decreased, the households did not want to give up the houses because they expected that the house value would go up in the near future during the period of 2005-2007 and 2007-2009. The other possible factor is that the households with decreased family income were more likely to keep their houses during the period of 2005-2007 and 2007-2009 than during the period of 2009-2011 because of the loose bank mortgage policies.

Third, the estimated coefficients of the employment status of wife in 2011 are significant for switching to renter in Table III. The household with employed wife in 2011 was less likely to switch from home owner to renter. But, the corresponding estimated coefficient in the period of 2007-2009 is not significant. In 2009, there are many other more important factors, such as the previous risky mortgage position and the worry for the future, that affect the transition from home owner to renter, and then the employment status of wife in 2009 was not that important relatively.

Now, let's analyze the effect of mortgage distress on the transition from home owner to renter. According to the results for switching to renter in Table III, we can see that the mortgage distress is a very significant factor for the transition from home owner to renter. We get the same significant result for both mortgage distress indexes. The home owners with mortgage distress in 2009 were significantly more likely to switch to renter in 2011. There is no surprise for this result. The households with mortgage payment problems would have to foreclosure their mortgages and give up their houses.

\section{CONCLUSION}

In this paper, I analyze the factors that affect household decision of owning/renting, transition from renter to home owner, and transition from home owner to renter. To capture the different household actions before and during the financial crisis, I do the analysis in both the period of 2007-2009 and the period of 2005-2007, and some interesting differences are found between those two periods.

Young people were less likely to own houses, and they were more likely to switch from renters to home owners during the regular or good time periods. Households headed by people with high education level were more likely to be home owners, and they were more likely to switch from renters to home owners. The employment status and marriage status play some roles in both the decision of owning/renting and the transition between home owner and renter. Household wealth level and annul family income level 
significantly affect both the decision of owning /renting and the transition between home owner and renter.

By exploiting the new released 2011 PSID survey data, we can exam the effect of mortgage distress on the transition from home owner to renter. The empirical results show the strong significant effect of mortgage distress on the transition from home owner to renter.

\section{REFERENCES}

[1] E. Hurst, M. C. Luoh, and F. P. Stafford, "Wealth dynamics of American families, 1984-1994," Brooking Papers on Economic Activity, vol. 98, no. 1, pp. 267-338, 1998.

[2] E. N. Wolff, "Recent trends in household wealth in the United States: rising debt and the middle-class squeeze-an update to 2007," Working Paper, no. 589, Levy Economics Institute of Bard College, 2010.

[3] R. Bostic, S. Gabriel, and G. Painter, "Housing wealth, financial wealth, and consumption: new evidence from micro data," Regional Science and Urban Economics, vol. 39, pp. 79-89, January 2009.

[4] E. Hurst and F. P. Stafford, "Home is where the equity is: mortgage refinancing and household consumption," Journal of Money, Credit and Banking, vol. 36, pp. 985-1014, December 2004.
[5] D. Cooper, "Essays on housing wealth and consumer behavior," Ph.D dissertation, Department of Economics, University of Michigan, Ann Arbor, MI, 2009

[6] D. C. Ling and A. Naranjo, "The integration of commercial real estate markets and stock markets," Real Estate Economics, vol. 27, pp. 483-515, September 1999.

[7] J. Okunev and P. J. Wilson, "Using nonlinear tests to examine integration between real estate and stock markets," Real Estate Economics, vol. 25, pp. 487-503, September 1997.

[8] F. P. Stafford and B. Chen, "Diminishing margins: housing market declines and family financial responses," Working Paper 2012-276, Michigan Retirement Research Center, December 2012.

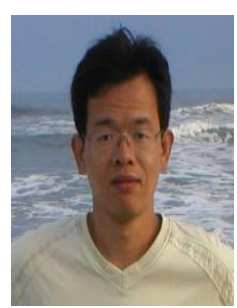

Bing Chen is a postdoctoral fellow at Bowdoin College at Brunswick, ME 04011 USA. His research areas include household analysis, macroeconomics, applied econometrics, and real estate finance. 